\title{
Learning Writing Explanatory Text by Using the Process Approach
}

\author{
Fitri Handayani* \\ Indonesian Language and Literature Education of Graduate \\ School \\ Universitas Negeri Yogyakarta \\ Yogyakarta, Indonesia \\ fitrihandayani.2016@student.uny.ac.id
}

\author{
Ari Kusmiatun \\ Indonesian Language and Literature Education of Graduate \\ School \\ Universitas Negeri Yogyakarta \\ Yogyakarta, Indonesia \\ bu_arik@yahoo.com
}

\begin{abstract}
This study aims to describe process and achievement of expository writing skills through the process approach. This study used classroom action research design assigning 31 students in the eleventh graders of SMK Negeri 2 Yogyakarta. The study was conducted in two cycles each of which was staged using planning, implementation, observation, and reflection. The results of data analysis showed: (1) attainment in writing expository writing after process approach was incurred in cycle 1 and cycle 2 increased from $76 \%$ into $89 \%$; (2) the learning process showed that in cycle 1 , students were successful to understand text structure of explanation writing; and in cycle 2 students accomplished minimum standard of mastery. During the learning process: initial, core, concluding stages, students enthusiastically followed each stage of learning at their own interests and struggles.
\end{abstract}

Keywords-writing, explanatory text, process approach, action research

\section{INTRODUCTION}

Indonesian is one of the compulsory subjects to be taught at all levels of education in all institutions in formal education. Language skills includes four aspects: listening, speaking, reading, and writing. Writing is one of the aspects of language skills. Therefore, the writing skills should be emphasized. In the teaching of writing, especially writing explanatory text at SMK Negeri 2 Yogyakarta students' ability to write explanatory text has not reached KKM (Complete Minimal Criteria) expected. Starting from that, the researchers seek to make improvements to enhance the explanatory text writing skills class XI student of SMK Negeri 2 Yogyakarta ie through the process approach. Results of preliminary observations indicate, most students do not yet have the skills to write particular text as expected. They consider writing explanatory text in accordance with the most difficult EYD because they feel a lot of ideas that cannot be written. Based on the analysis of basic competences and interviews with teachers, learning interesting approach is needed to improve students' skills in writing skills. According to Indonesian teachers

studied, it is known that the interest of the students towards learning to write very less and abilities of students in learning to write is still low. Therefore, researchers are interested to make improvements in the teaching of writing by conducting research to improve writing skills with a focus on writing text explanations using a process approach. They consider writing explanatory text in accordance with the most difficult EYD because they feel a lot of ideas that cannot be written. Based on the analysis of basic competences and interviews with teachers, learning interesting approach is needed to improve students' skills in writing skills. According to Indonesian teachers studied, it is known that the interest of the students towards learning to write very less and abilities of students in learning to write is still low. Therefore, researchers are interested to make improvements in the teaching of writing by conducting research to improve writing skills with a focus on writing text explanations using a process approach (Coulmas, 2003). They consider writing explanatory text in accordance with the most difficult EYD because they feel a lot of ideas that cannot be written. Based on the analysis of basic competences and interviews with teachers, learning interesting approach is needed to improve students' skills in writing skills. According to Indonesian teachers studied, it is known that the interest of the students towards learning to write very less and abilities of students in learning to write is still low. Therefore, researchers are interested to make improvements in the teaching of writing by conducting research to improve writing skills with a focus on writing text explanations using a process approach. Interesting learning approach is necessary to improve students' skills in writing skills. According to Indonesian teachers studied, it is known that the interest of the students towards learning to write very less and abilities of students in learning to write is still low. Therefore, researchers are interested to make improvements in the teaching of writing by conducting research to improve writing skills with a focus on writing text explanations using a process approach. interesting learning approach is necessary to improve students skills in writing skills. According to Indonesian teachers studied, it is known that the interest of the students towards learning to write very less and abilities of students in learning to write is still low. Therefore, researchers are interested to make improvements in the teaching of writing by conducting research to improve writing skills with a focus on writing text explanations using a process approach. 
Writing is a form of thought, but rather to think for certain readers, and at a certain time. One of the most important duties of the writer as a writer is to master the principles of writing and thinking that will be able to help him achieve his aim. The most important among the principles that meant it was a discovery, composition, and style (Joshua, 2009; Janjic: 200. According to Anderson (1980: 5) in Tarigan (2008: 23) learning to write is to think in / in a certain way. Morris in Tarigan (2008: 7) points out that good writing is communication of thoughts and feelings effectively. The purpose of writing is projecting something of oneself. Writing does not require selecting a subject suitable and appropriate,

In the book Indonesian Students Mandiri Curriculum 2013 (Kosasih, et al, 2013: 85-86) states that the explanatory text is text that describes or explains the process or natural and social phenomena. Explanatory text structure includes identification of the phenomenon, the chronology of events, and reviews. The process approach is an approach which is seen creative writing can facilitate students learning to write. The process approach is an approach to teaching that gives students the chance to participate live the process of the invention or the preparation of a concept as a writing skills (Sagala, 2009: 74).

Some of the advantages of the process approach, among others: (1) gives stock way of acquiring knowledge is very important for the development of future knowledge, and (2) the introduction is creative and requires students to be active so that it can improve thinking skills and how to acquire knowledge (Sagala, 2009: 74). According to Tompkins and Hoskisson (1995: 211) focusing on the process of writing lies in what students think and do in the writing process. There are five stages in the process approach, namely (1) prapenulisan phase, (2) the stage of drafting, (3) the stage of revising, (4) the stage of editing, and (5) the publication stage .

\section{RESEARCH METHOD}

This research was conducted using qualitative approach with classroom action research design (classroom action research). The study was conducted in the form of a cycle and each cycle includes: (1) planning, (2) implementation, (3) observation (4) reflection, because this research aims to improve, enhance classroom practice in a sustainable manner and resolve problems faced by a teacher in the classroom.

The research was conducted at SMK Negeri 2 Yogyakarta on grade students who are 32 pupils and implemented in November 2019. The material is the focus of this research is to find information for a discussion via text eskplanasi. The subjects were students of class XI numbered 32 people, consisting of 17 female 15 male. Data were collected through techniques: observation, testing and interview.
III. RESEARCH RESULTS

Table 1. RESULT OF LEARNING, ACTIVITIES AND CLASSROOM MANAGEMENT

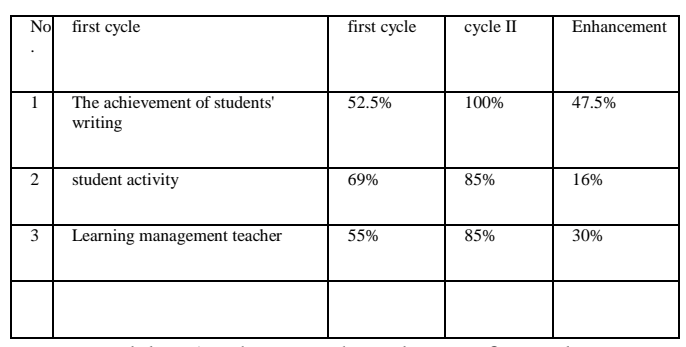

Table 1 shows the data of student success. This success was aided by the approach of the process that has been used as much as possible by the whole student. With this approach, students are no more difficulty when writing in the discussion forum. It shows that process approach has the advantage of helping students learn writing.

Table 1 shows the students' skills in reading in the first cycle and the second cycle on the rise: $52.5 \%$ in the first cycle and the second cycle assessment results discussion reaches $100 \%$. The data shows the process approach is a form of innovation in improving the quality of teaching and learning process that aims to help students to learn independently and creatively, so that students can acquire the knowledge, skills and attitudes that can form the personality of the student.

The results of writing skills using the approach of this process shows that the students' skills in writing, especially on learning find information in writing by writing eskplanasi increased well (Djibran, 2008; Gerot, 1994; Knapp, 2005). During the learning process from the initial phase, the core stage, to cover, during the first cycle of students enthusiastically followed each stage of learning and on the second cycle students were very enthusiastic to follow each stage of learning. Can be described in the learning process approach to writing begins with the formation of heterogeneous groups, pemberiaan for discussion, implementation of discussion and reflection.

\section{A. DISCUSSION}

The discussion in this article includes a discussion of the process and the resulting increase students' writing skills through a process approach in SMK 2 Yogyakarta. The discussion process is based on a process of improving writing skills, especially in learning find information for discussions text eskplanasi through a process approach during the implementation phase and the implementation phase of the first cycle of the second cycle. The process in the first cycle and the second cycle is the teacher explains the material on how to find information for discussions with the approach that will be used in the process of learning.

After carrying out observations and based on interviews with teachers Indonesian researchers found that the problem lies in the difficulty of students to find information 
for a discussion via text eskplanasi. This was seen at the time of writing tesk eskplanasi, bahwasannya not all students can find information for discussion.

\section{FIRST CYCLE}

In this learning process served time $3 \times 45$ minutes that teachers plan and carry out the formation of the group. In the first cycle researchers divided the group. Steps in applying the process approach is as follows:

Here are the stages of learning to write explanatory text using a process approach:

\section{a. Prewriting}

1) Students determine the topic of the theme given by the teacher. Teachers provide explanatory text theme is a natural phenomenon.

2) After determining the topic, the students then formulate goals and determine the form of writing.

3) Students will also determine its target audience. In this case the student determines that readers are their own friends.

\section{b. Drafting}

1) Students begin to develop an idea or ideas into a sentence, and then develop it into a paragraph.

2) Each paragraph has been written later developed into a discourse temporary or draft.

3) In this phase, students are only required to float the idea without regard to fault the preparation of a sentence, spelling, and punctuation. The focus is on the process of casting ideas into a discourse.

\section{c. Revising}

1) Students are required to read again the draft that have previously been made.

2) Students are also asked to check the writing in its content if it is appropriate to the topic and purpose designed.

3) Students then swap framework or draft that he had made with friends in the group.

4) Each student then editing or revisions to the draft posts made by friends. Some of the improvements include the correction of word choice, spelling, and punctuation.

\section{d. Editing}

1) Students read back the draft which has been corrected by his friends.

2) Students make corrections to errors in his writing.

3) Draft repaired then written back in full so as to produce good writing.
The last stage in the process approach is the publication stage. In this stage, posts made by students typed then collected into a book. The book was later donated in the school library. A token of appreciation like this can give rise to self-confidence in students and to motivate them to become a writer/author. In addition, the appreciation of this kind also makes the students to dare to write texts or other storyline. This can increase the motivation of students in terms of writing skills.

\section{SECOND CYCLE}

In the process of implementation of the second cycle also directly entered into discussions with well and students also feel no more difficulty for assisted with the process approach during the discussions to find information in writing and the whole group was given time to discuss the return articles that have been provided by the researchers.

But if the first cycle occurred bahwasannya other students waiting for the results of his friends and looks still shy in discussing, in the second cycle of researchers gives the directives again more leverage and continue to observe all of the students during the implementation of the discussion and the students made little progress in writing. This means that process approach helps students to overcome difficulties in writing.

Furthermore, the activities carried out in the second cycle, the researchers randomly selecting groups to present the results of discussion with the group. In this case the researchers put more emphasis on students who have not succeeded in the first cycle. The purpose of this activity is to stimulate the courage, accuracy, precision, smoothness, and also use standard Indonesian students so that they can be motivated by their learning like this. With the approach of the process, students are very helpful at all in terms of explanatory text.

\section{CONCLUSION}

Based on the explanation above, then the next it can be concluded that after the process that has been implemented in the first cycle and the second is no improvement on behavioral changes in students. It also affects the results obtained by students' grades. In the first cycle acquisition results of students in writing skills after using a process approach that of the 32 students there are 20 students who completed both the assessment of writing is $52.5 \%$, while students who did not complete there are 12 students who are acquiring the percentage was $47.5 \%$. In the second cycle increase student scores on reading assessment results so drastic that the results of the acquisition of writing the percentage is $100 \%$. With the approach of the process, the students focus on writing activities especially in the teaching of writing eskplanasi to find information for discussion.

\section{e. Publications}


In the 2013 curriculum, learning Indonesian intended that learners are able to listen, read, you watch, speak and write. One of the goals of the highlights writer is the aim that the learners are able to write. The act of writing in Indonesian subjects contained in the syllabus of class XI, KD 4.4 which produces explanatory texts orally or in writing with notice and linguistic structure. The basic competence indicated that one of students' learning is to write explanatory text. To achieve these objectives, Indonesian teachers can use one of the co-operative approach is the approach process.

The process approach is an approach that provides syntax or learning steps in accordance with the teaching materials that will be implemented. Syntax based process approach, teachers choose topics to stimulate students to develop ideas and ideas into an article. The topics chosen by teachers are topics that are close to student life. This is done so that students can more easily in expressing ideas in writing so that it becomes a good explanatory text. Thus, based on the stages of the learning process approach in the explanatory text writing process approach helps students to reach all learning objectives explanatory text. This is done so that students can more easily in expressing ideas in writing so that it becomes a good explanatory text. Thus, based on the stages of the learning process approach in the explanatory text writing process approach helps students to reach all learning objectives explanatory text. This is done so that students can more easily in expressing ideas in writing so that it becomes a good explanatory text. Thus, based on the stages of the learning process approach in the explanatory text writing process approach helps students to reach all learning objectives explanatory text.

\section{REFERENCES}

Anderson, Mark dan Kathy Anderson. 1997. Text Types In English. Rg4poMalaysia: Macmillan Education Australia.

Coulmas, Florian. 2003. Writing Systems: An Introduction to their Linguistic Analysis. New York: Cambridge University Press.

Djibran, Fahd. 2008. Writing is Amazing. Yogyakarta: Juxtapose.

Gerot, Linda dan Peter Wignel. 1994. Making Sence of a Functional Grammar. Australia: Gerd Strable.

Janjic, Watrich, Vera, "The Cambridge Handbook Of Literacy" by Olson, D.R. \& Torrance, R. (Eds). Books Review. Alberta”. Journal of Educational Research, Winter, Vol 55, No 4 (2009).

Josua, Helena Megameno N. 2009. Improving explanation writing skills of Junior Secondary Learners in Life Sciences: A case study. Rhodes University.

Knapp, Peter dan Megan Watkins. 2005. Genre, Text, Grammar. Australia: University of New South Wales.

Sagala, Syaiful. 2009. Konsep dan Makna Pembelajaran. Bandung: Alfabeta.

Tompkins, Gail E. dan Kenneth, Horkisson. 1995. Language Art Contents and Teaching Strategies. New Jersey: Englewood Clifts. 